\title{
Model Problem Based Learning dengan Pendekatan Multi Representasi untuk Meningkatkan Kemampuan Memecahkan Masalah Siswa dengan Tingkat Self-Efficacy Berbeda
}

\author{
Agustina Dinda Putri Larasati ${ }^{1}$, Suhadi Ibnu ${ }^{1}$, Aman Santoso ${ }^{1}$ \\ ${ }^{1}$ Pendidikan Kimia-Universitas Negeri Malang
}

\section{INFO ARTIKEL}

\section{Riwayat Artikel:}

Diterima: 09-04-2019

Disetujui: 26-06-2019

\begin{abstract}
Kata kunci:
problem based learning model; solution to problem;

multi representation approach; model problem based learning; pemecahan masalah;

pendekatan multi representasi
\end{abstract}

\author{
Alamat Korespondensi: \\ Agustina Dinda Putri Larasati \\ Pendidikan Kimia \\ Universitas Negeri Malang \\ Jalan Semarang 5 Malang \\ E-mail: dindaa246@gmail.com
}

\section{ABSTRAK}

\begin{abstract}
This study aimed to look at the effectiveness of the PBL-MR learning model to improved problem solving skills of students with different levels of self-efficacy. The effectiveness was seen from the difference in the level of problem solving of students in the topic of reaction rate PBL-MR and PBL learning models. The difference in the level of self-efficacy was seen from the differences of self-efficacy of students in one class where the students had been grouped into high and low levels of self-efficacy based on the questionnaire. This study used an essay test instrument that had a content validity of $94 \%$ with a very good category and a reliability coefficient of 0.842 with very high reliability criteria. The research sample was taken from two 11th year classes of SMAN 2 Malang. The results showed that there were statistically significant differences in problem solving abilities of students in both research classes (sig. 0.000) and there were also differences in problem solving skills between students with high and low levels of self-efficacy (sig. 0.028). The interaction of the model and self efficacy also produce significant impacts on problem solving ability (sig. 0,042).
\end{abstract}

\begin{abstract}
Abstrak: Penelitian ini bertujuan untuk melihat keefektifan model pembelajaran $P B L-$ MR untuk meningkatkan kemampuan memecahkan masalah siswa dengan tingkat selfefficacy yang berbeda. Keefektifan dilihat dari perbedaan tingkat pemecahan masalah siswa pada materi laju reaksi melalui model pembelajaran $P B L-M R$ dan model $P B L$. Perbedaan tingkat self-efficacy dilihat dari adanya perbedaan tingkat self-efficacy siswa dalam satu kelas yang telah dikelompokkan menjadi siswa dengan tingkat self-efficacy tinggi dan rendah berdasarkan angket. Penelitian ini menggunakan instrumen tes essay yang memiliki validitas isi $94 \%$ dengan kategori sangat baik dan koefisien reliabilitas 0,842 dengan kriteria reliabilitas sangat tinggi. Sampel penelitian diambil dari dua kelas XI MIPA SMAN 2 Malang. Hasil penelitian menunjukkan adanya perbedaan yang signifikan secara statistik terhadap kemampuan memecahkan masalah siswa di kedua kelas penelitian (sig. sebesar 0.000) dan terdapat perbedaan kemampuan memecahkan masalah antara siswa dengan tingkat self-efficacy tinggi dan rendah (sig. sebesar 0,028). Interaksi antara model pembelajaran dan tingkat self-efficacy dengan kemampuan memecahkan masalah siswa memperoleh hasil yang cukup signifikan (sig. sebesar 0,042).
\end{abstract}

Pendidikan berperan penting dalam kehidupan manusia. Seiring kemajuan teknologi dan ilmu pengetahuan menuntut manusia untuk berpikir efektif, kreatif, dan inovatif demi peningkatan kualitas sumber daya manusia sehingga mampu bersaing dalam persaingan dunia global. Keterampilan abad ke-21 masih relevan dengan empat pilar kehidupan yakni learning to do, learning to know, learning to be, learning to live together. Empat prinsip tersebut masing-masing mengandung keterampilan khusus yang perlu diberdayakan dalam kegiatan belajar, seperti pemecahan masalah, berpikir kritis, metakognisi, keterampilan berkomunikasi, berkolaborasi, inovasi dan kreasi, literasi informasi (Daryanto, 2015). Pembelajaran yang disesuaikan dengan kebutuhan pada abad-21 juga diterapkan pada mata pelajaran Kimia yang telah dirancang agar peserta didik dapat memahami dan menerapkan pengetahuan yang didapat dalam kehidupan sehari-hari. Kimia merupakan salah satu rumpun ilmu yang termasuk ke dalam Ilmu Pengetahuan Alam yang mengkhususkan bahasannya pada struktur dan komposisi zat, perubahan, dan energi yang menyertai 
perubahan tersebut. Proses pembelajaran kimia menekankan pada pemberian pengalaman langsung untuk mengembangkan keterampilan dan sikap agar peserta didik mampu menjelajahi dan memahami alam sekitar secara ilmiah (Mulyasa, 2005). Karakteristik materi kimia yang menekankan pada aplikasi dalam kehidupan sehari-hari menuntut peserta didik dapat memecahkan setiap permasalahan yang diberikan oleh guru dengan baik sehingga diperlukan suatu model pembelajaran yang dapat mengasah kemampuan memecahkan masalah pada peserta didik.

Materi kimia yang banyak penerapannya dalam kehidupan sehari-hari salah satunya adalah laju reaksi. Berdasarkan hasil analisis terhadap materi laju reaksi didapatkan bahwa laju reaksi memuat konsep abstrak, hitungan matematis, grafik dan melibatkan multi representasi (Musya'idah, Effendy, \& Santoso, 2016). Atas dasar itulah, konsep-konsep dalam materi laju reaksi harus dapat dibuktikan dengan melakukan suatu percobaan praktikum. Hasil penelitian (Sanova, 2013) menyatakan penerapan metode Problem Based Learning berbantuan Diagram Vee dalam pembelajaran kimia berbasis virtual lab dapat meningkatkan pemahaman konsep belajar siswa. Tidak hanya dengan praktikum, materi laju reaksi juga dapat diajarkan melalui sebuah fenomena nyata yang membutuhkan solusi dalam memecahkan permasalahan yang diambil berdasarkan fenomena yang disajikan. Melalui proses pemecahan masalah peserta didik dapat terlibat aktif dalam proses pembelajaran sehingga proses belajar mengajar tidak hanya terpusat pada guru saja (teacher centered), melainkan student centered (Imama \& Nasrudin, 2015).

Model pembelajaran yang merupakan aplikasi pembelajaran aktif dan dapat meningkatkan minat belajar siswa adalah model Problem Based Learning. PBL merupakan model pembelajaran interaktif dan inovatif yang dapat memberikan kondisi belajar aktif pada peserta didik saat pembelajaran dengan melibatkan peserta didik untuk mengeksplorasi masalah-masalah kontekstual yang berhubungan dengan kehidupan sehari-hari serta memecahkannya melalui tahap-tahap metode ilmiah (Arends, 2012). Berdasarkan hasil penelitian pembelajaran dengan menggunakan Problem Based Learning pada materi laju reaksi dapat meningkatkan kemampuan berpikir kritis dan hasil belajar siswa. Model pembelajaran PBL dikatakan lebih efektif daripada model pembelajaran Direct Instruction (Handayani, 2016).

PBL dibangun atas prinsip konstruktif, kontekstual mandiri, dan kolaboratif. Prinsip kontekstual ini memiliki landasan pada falsafah belajar konstruktivisme. Konstruktivisme menekankan bahwa belajar tidak hanya sekedar menghafal, melainkan mengonstruksi pengetahuan siswa. Model pembelajaran berbasis masalah ini dapat membantu peserta didik dalam membangun konsep abstrak, tetapi pada materi laju reaksi ini tidak hanya menekankan pada pembelajaran makroskopis sebaliknya lebih menekankan pada pemberian pengalaman belajar pada peserta didik dengan multi representasi (makroskopis, sub simbolik, dan simbolik) sehingga dibutuhkan pendekatan yang mampu membantu pemahaman konsep peserta didik.

Pendekatan multi representasi merupakan bentuk representasi yang memadukan antara teks, gambar nyata, atau grafik. Pembelajaran dengan multi representasi diharapkan mampu untuk menjembatani proses pemahaman peserta didik terhadap konsep-konsep kimia. Penelitian (Herawati, Mulyani, \& Redjeki, 2013) menyatakan bahwa pembelajaran multi representasi lebih baik dibandingkan dengan menggunakan pembelajaran konvensional pada materi pokok laju reaksi sehingga pembelajaran kimia pada materi pokok laju reaksi sebaiknya disajikan dengan multi representasi karena dengan penggunaan representasi yang bermacam-macam dapat membuat konsep-konsep menjadi lebih mudah dipahami dan menyenangkan sehingga dapat meningkatkan motivasi peserta didik untuk belajar. Penelitian Mustofa (2016) menunjukkan bahwa kemampuan berpikir terutama kemampuan memecahkan masalah peserta didik SMA kelas X SMA Negeri di Malang masih pada kategori sedang bahkan ada juga yang masih tergolong rendah. Kemampuan memecahkan masalah tersebut, yaitu (1) kemampuan dalam merumuskan masalah; (2) kemampuan dalam menyusun hipotesis; (3) kemampuan mengumpulkan data; (4) pengujian hipotesis atau penarikan kesimpulan; (5) pengambilan keputusan.

Kesulitan dalam memecahkan masalah yang dialami peserta didik dapat disebabkan beberapa faktor salah satunya adalah faktor interen, yaitu keyakinan dan persepsi (Sholikhah, 2017). Peserta didik satu dengan peserta didik yang lain masing-masing memiliki keyakinan dan persepsi yang berbeda. Perbedaan tersebut berupa perbedaan kognitif, afektif, psikologis, dan sebagain ya perlu diketahui dan diperhatikan oleh guru (Novferma, 2016). Didukung dengan pendapat Yates (Novferma, 2016) bahwa guru perlu mengetahui apa yang peserta didik rasakan, pikirkan, dan lakukan. Pengaruh dari sikap, nilai, karateristik kepribadian terhadap partisipasi dalam pembelajaran penting untuk menjadi pertimbangan bagi para pendidik.

Penelitian (Jatisunda, 2017) mengungkapkan terdapat hubungan yang positif antara kemampuan pemecahan masalah matematis dan self-efficacy peserta didik. Berdasarkan penelitian tersebut, self-efficacy memiliki fungsi sebagai alat untuk menilai keberhasilan peserta didik dalam menyelesaikan soal-soal pemecahan masalah. Seorang peserta didik yang memiliki kemampuan pemecahan masalah matematis yang baik maka seorang peserta didik tersebut pun memiliki self-efficacy yang baik pula. Hasil penelitian (Pajares \& Miller, 1994) melaporkan bahwa dengan self-efficacy yang tinggi, maka pada umumnya seorang peserta didik akan lebih mudah dan berhasil melampaui latihan-latihan matematika yang diberikan kepadanya sehingga hasil akhir pembelajaran tersebut tercermin dalam prestasi akademiknya cenderung lebih tinggi dibandingkan peserta didik yang memiliki prestasi akademik rendah.

\section{METODE}

Rancangan penelitian ini ialah eksperimental semu dengan pre-test dan post-test pada dua kelompok (quasi experimental pretest-postest). Sampel yang diambil diasumsikan memiliki kemampuan awal yang sama antara peserta didik satu dengan lainnya sehingga teknik pengambilan menggunakan teknik cluster random sampling. Kedua kelas mendapat perlakuan yang berbeda, untuk kelas eksperimen dengan populasi sampel sebanyak 31 siswa diajarkan dengan menggunakan model pembelajaran PBL 
dengan pendekatan multi representasi, sedangkan untuk kelas kontrol dengan populasi sampel sebanyak 32 siswa hanya diajarkan dengan menggunakan model pembelajaran PBL. Lebih jelasnya desain eksperimen pada penelitian ini dapat dilihat pada tabel 1.

Tabel 1. Rancangan Penelitian

\begin{tabular}{cccc}
\hline Kelompok & Pre-test & Perlakuan & Post-test \\
\hline Eksperimen & O1 & $\mathrm{X}$ & $\mathrm{O} 2$ \\
\hline Kontrol & $\mathrm{O} 3$ & - & $\mathrm{O} 4$ \\
\hline \multicolumn{4}{c}{ (Ibnu, 2003) }
\end{tabular}

Keterangan:

$\mathrm{X}$ : Perlakuan yaitu penggunaan model pembelajaran PBL dengan pendekatan multi representasi

- : Perlakuan dengan menggunakan model pembelajaran PBL

O1 : Skor pre-test kelompok eksperimen

O2 : Skor post-test kelompok eksperimen

O3 : Skor pre-test kelompok kontrol

O4 : Skor post-test kelompok kontrol

Adanya variabel moderator tingkat self-efficacy peserta didik yang akan dilihat pengaruhnya maka rancangan eksperimental semu pada penelitian ini dikembangkan menjadi desain eksperimen factorial $2 \times 2$. Desain ini secara skematis digambarkan pada tabel 2 .

Tabel 2. Rancangan Two Factorial Design

\begin{tabular}{|c|c|c|c|}
\hline \multirow{2}{*}{\multicolumn{2}{|c|}{$\begin{array}{l}\text { Variabel bebas/ } \\
\text { Variabel Moderator }\end{array}$}} & \multicolumn{2}{|c|}{ Model Pembelajaran } \\
\hline & & $\begin{array}{c}\text { PBL-Multi Representasi } \\
\left(\mathbf{X}_{1}\right)\end{array}$ & $\begin{array}{l}\text { PBL } \\
\left(\mathbf{X}_{2}\right) \\
\end{array}$ \\
\hline Self-efficacy & $\begin{array}{l}\text { Tinggi }\left(\mathrm{Y}_{1}\right) \\
\text { Rendah }\left(\mathrm{Y}_{2}\right)\end{array}$ & $\begin{array}{l}\mathrm{X}_{1} \mathrm{Y}_{1} \\
\mathrm{X}_{1} \mathrm{Y}_{2}\end{array}$ & $\begin{array}{l}\mathrm{X}_{2} \mathrm{Y}_{1} \\
\mathrm{X}_{2} \mathrm{Y}_{2}\end{array}$ \\
\hline
\end{tabular}

Keterangan:

$\mathrm{X}_{1} \mathrm{Y}_{1}$ : Kemampuan memecahkan masalah peserta didik self-efficacy tinggi dengan menggunakan model pembelajaran PBLMR.

$\mathrm{X}_{2} \mathrm{Y}_{1}$ : Kemampuan memecahkan masalah peserta didik self-efficacy tinggi dengan menggunakan model pembelajaran PBL.

$\mathrm{X}_{1} \mathrm{Y}_{2}$ : Kemampuan memecahkan masalah peserta didik self-efficacy rendah dengan menggunakan model pembelajaran PBLMR.

$\mathrm{X}_{2} \mathrm{Y}_{2}$ : Kemampuan memecahkan masalah peserta didik self-efficacy rendah dengan menggunakan model pembelajaran PBL.

\section{HASIL}

Kemampuan memecahkan masalah siswa diperoleh dari hasil jawaban siswa terhadap tes pemecahan masalah materi laju reaksi yang terdiri dari tiga butir soal essay berinduk dengan total soal keseluruhan sebanyak sebelas butir. Berikut ini nilai rata-rata perolehan skor pemecahan masalah siswa pada materi laju reaksi ditinjau dari skor pre-test dan post-test yang ditunjukkan pada tabel 3 .

Tabel 3. Nilai Rata-Rata Pre-test dan Post-test Kemampuan Memecahkan Masalah Siswa

\begin{tabular}{ccc}
\hline & \multicolumn{2}{c}{ Rata-rata Nilai } \\
\cline { 2 - 3 } & Pre-test & Post-test \\
\hline Kelas Eksperimen & 56 & 91 \\
\hline Kelas Kontrol & 56 & 81 \\
\hline
\end{tabular}

Tabel 3 menunjukkan bahwa tidak ada perbedaan nilai rata-rata pre-test soal pemecahan masalah antara kelas kontrol dan eksperimen, sedangkan setelah diberikan perlakuan berbeda terdapat perbedaan nilai rata-rata post-test dengan soal yang sama, dimana rata-rata skor kelas eksperimen lebih tinggi dibandingkan dengan kelas kontrol. Sebelum dilakukan pengujian dugaan, data tes pemecahan masalah harus diuji prasyarat untuk mengetahui analisis statistik yang digunakan pada uji hipotesis. Uji prasyarat yang dilakukan yaitu uji normalitas menggunakan uji normalitas two-way ANOVA berdasarkan nilai Standardized Residual dengan SPSS 23.0 for Windows dan uji homogenitas menggunakan Levene Statistic.

Uji normalitas pada data tes pemahaman konsep menunjukkan bahwa data terdistribusi normal dengan perolehan Sig. sebesar 0,403. Uji homogenitas ini menunjukkan bahwa data pemecahan masalah siswa dari kedua kelas adalah homogen dengan perolehan nilai Sig. sebesar 0,083. Berdasarkan uji kesamaan dua rata-rata dengan menggunakan Independent T-test Sample untuk 
melihat kemampuan awal kedua kelas diperoleh nilai Sig. sebesar 0,513 yang berarti tidak terdapat perbedaan kemampuan memecahkan masalah berdasarkan nilai pre-test kedua kelas penelitian. Berdasarkan hasil uji prasyarat data pre-test dan data post-test materi laju reaksi pada kelas eksperimen dan kelas kontrol, kedua kelas tersebut terdistribusi normal dan memiliki varians yang homogen. Oleh sebab itu, uji hipotesis yang sesuai digunakan adalah uji ANOVA dua jalur. Hasil uji dengan bantuan program SPSS 23 for windows ditunjukkan pada tabel 4.

Tabel 4. Hasil Uji Hipotesis dengan ANOVA Dua Jalur

\begin{tabular}{cccccc}
\hline Source & Type III Sum of Squares & df & Mean Square & F & Sig. \\
\hline Model Pembelajaran & 1435.944 & 1 & 1435.944 & 24.080 & .000 \\
Tingkat SE & 302.666 & 1 & 302.666 & 5.076 & .028 \\
Model Pembelajaran Tingkat SE & 258.403 & 1 & 258.403 & 4.333 & .042 \\
\hline
\end{tabular}

Berdasarkan tabel 4 dapat disimpulkan bahwa pembelajaran $P B L-M R$ memberikan dampak positif yang signifikan terhadap kemampuan memecahkan masalah siswa pada materi laju reaksi dibandingkan dengan pembelajaran $P B L$. Setelah itu dilakukan uji efektivitas pada kedua model pembelajaran yang diterapkan dengan melihat ketuntasan klasikal pada masing-masing kelas. Perbedaan ketuntasan klasikal pada kedua kelas dapat dilihat pada gambar 2. Tabel 4 juga memberikan hasil bahwa ada perbedaan kemampuan memecahkan masalah antara siswa dengan tingkat self-efficacy tinggi dan rendah dengan perolehan nilai Sig. sebesar 0,028 yang berarti $\mathrm{H}_{0}$ ditolak dan $\mathrm{H}_{1}$ diterima. Adanya perbedaan tingkat self-efficacy ini juga terlihat dari distribusi skor tiap kelas dapat dilihat pada gambar 2.

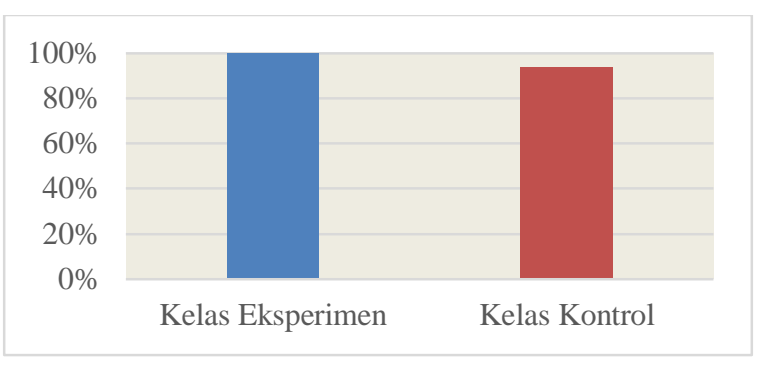

\section{Gambar 1. Persentase Perbandingan Ketuntasan Klasikal}

Gambar 1 menunjukkan perolehan ketuntasan klasikal kelas eksperimen lebih tinggi daripada kelas kontrol. Hal ini berarti model pembelajaran $P B L$-MR lebih efektif untuk meningkatkan kemampuan memecahkan masalah peserta didik. Model pembelajaran $P B L$ juga memperoleh persentase ketuntasan klasikal yang cukup tinggi hal ini berarti dengan menggunakan model $P B L$ juga sudah cukup mampu meningkatkan kemampuan memecahkan masalah hanya saja lebih efektif bila dipadukan dengan pendekatan MR.

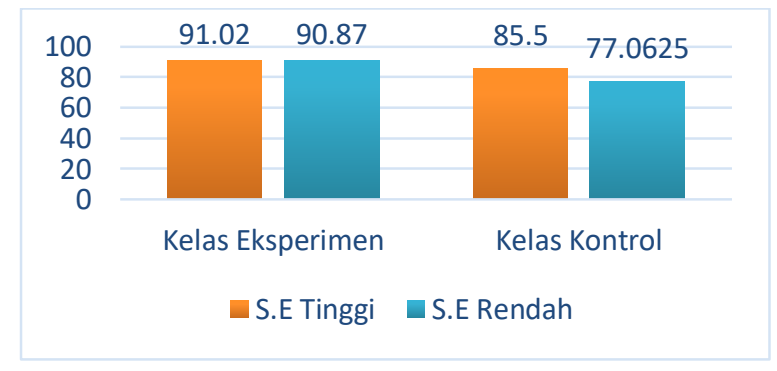

\section{Gambar 2. Hubungan Tingkat Self-Efficacy dengan Nilai Pemecahan Masalah}

Gambar 2 menunjukkan bahwa peserta didik yang memiliki self-efficacy tinggi cenderung memperoleh rata-rata nilai kemampuan pemecahan masalah yang tinggi pula walaupun selisih perolehan nilai antara peserta didik self-efficacy tinggi dan rendah tidak berbeda secara signifikan baik pada kelas kontrol maupun eksperimen.

Hasil analisis interaksi antara model pembelajaran dan tingkat self-efficacy terhadap kemampuan memecahkan masalah pada peserta didik diperoleh nilai Sig. sebesar $0,042<0,05$ sehingga $\mathrm{H}_{0}$ ditolak yang berarti terdapat interaksi antara model pembelajaran dan tingkat self-efficacy terhadap kemampuan memecahkan masalah peserta didik. 


\section{PEMBAHASAN}

Pada penelitian ini kemampuan memecahkan masalah peserta didik diukur berdasarkan nilai tes soal essay yang diberikan pada awal dan akhir selesainya materi laju reaksi. Saat mengerjakan soal tes peserta didik diminta untuk menyelesaikan tiap soal dengan empat tahapan pemecahan masalah menurut Polya yakni: analisis, perencanaan, penyelesaian/perhitungan, dan evaluasi. Keempat tahapan Polya telah dibelajarkan secara eksplisit dalam model pembelajaran $P B L$, dimana pada fase pertama dan kedua peserta didik diberikan masalah kemudian peserta didik menganalisis permasalahan yang dibantu dengan pertanyaanpertanyaan yang terkait untuk memudahkan mereka membangun konsepnya dan merumuskan hipotesis guna menjawab proses pemecahan masalah sehingga peserta didik dilatih untuk membuat suatu perencanaan sebelum melakukan penyelidikan. Kemudian pada fase ketiga peserta didik diminta untuk melakukan penyelidikan untuk membuktikan apakah analisis dan perencanaannya sudah sesuai dengan hasil eksperimen. Pada fase ketiga ini peserta didik dilatih untuk melakukan penyelesaian/perhitungan tergantung pada karakteristik submaterinya. Setelah itu pada fase keempat dan kelima peserta didik dilatih untuk melakukan evaluasi terhadap proses pemecahan masalah yang telah dibuat.

Berdasarkan hasil pretest dan post-test yang telah dilakukan terdapat perbedaan (data dapat dilihat pada gambar 1 dan tabel 1) Rentang perbedaan nilai post-test ini juga dipengaruhi oleh perolehan skor pada masing-masing aspek pemecahan masalah, karena peneliti menggunakan acuan tahapan pemecahan masalah menurut Polya sehingga soal tes essay juga harus dikerjakan oleh peserta didik sesuai dengan aspek-aspek pemecahan masalah menurut Polya. Saat pretest banyak peserta didik yang tidak mengerjakan soal essay sesuai aspek-aspek pemecahan masalah meskipun sudah terdapat petunjuk pengerjaan soal, hal ini mungkin dikarenakan mereka belum memahami apa maksud dari tiap aspek tersebut. Akan tetapi, pada saat post-test dengan soal yang sama dan terdapat petunjuk pengerjaan soal seluruh peserta didik mengerjakan runtut sesuai aspek-aspek pemecahan masalah. Aspek pemecahan masalah yang sering dilupakan oleh peserta didik adalah aspek evaluasi, peserta didik cenderung lupa memberikan evaluasi di akhir jawaban mereka sehingga nilai aspek evaluasi beberapa peserta didik ada yang memperoleh skor 0 . Perolehan rata-rata skor siswa dalam tes pemecahan masalah tiap aspeknya dapat dilihat pada gambar 3.

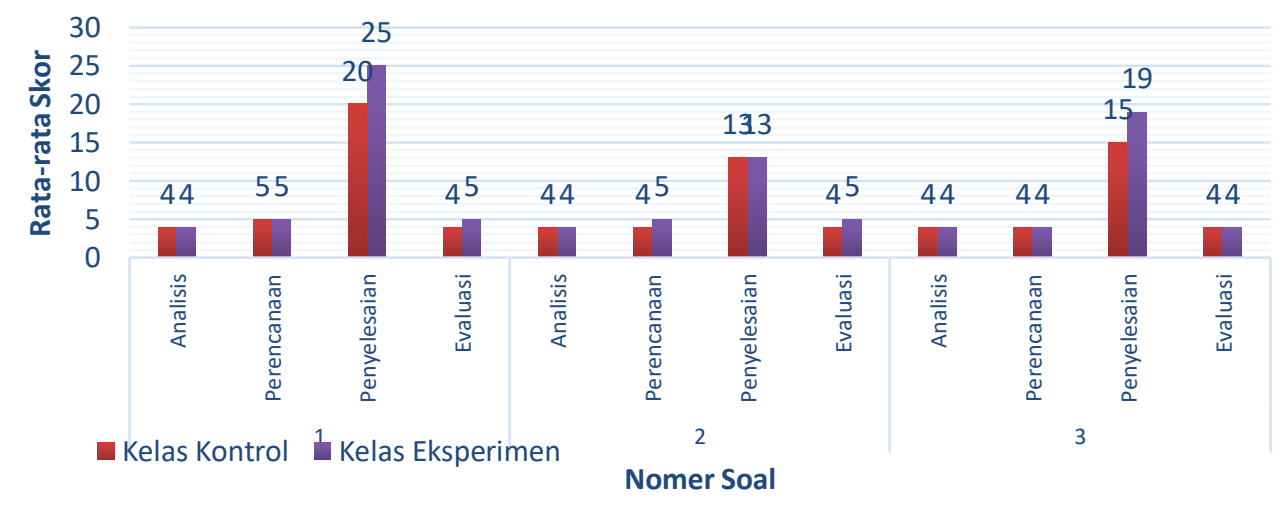

\section{Gambar 3. Perbandingan Nilai Post-test Pemecahan Masalah ditinjau dari Aspek Pemecahan Masalah}

Tahapan pertama, analisis adalah tahapan awal dimana peserta didik menganalisis masalahnya, saat menganalisis peserta didik dapat merumuskannya menjadi suatu pertanyaan yang memerlukan membuktian ataupun dapat berupa poin-poin terkait rangkuman dari masalah yang ada pada soal. Hal ini selaras dengan pendapat (Syaiful \& Aswan, 2006) dimana individu harus melokalisasi letak sumber kesulitan untuk memungkinkan mencari jalan pemecahannya. Pada tahap ini jawaban peserta didik sangat bervariasi, ada yang menganalisis dengan menggambar, ada pula yang menganalisis menjadi beberapa poin penting, dan ada pula yang membuat suatu rumusan masalah pada tahap ini.

Tahapan kedua, perencanaan peserta didik merencanakan proses pemecahan masalah dari apa yang mereka tahu. Melihat jawaban peserta didik pada tahap ini dapat terlihat peserta didik yang paham akan konsep pasti dapat merencanakan proses pemecahan masalah dengan baik, tetapi tidak sedikit pula peserta didik yang tidak menuliskan jawaban mereka pada tahapan ini. Peserta didik lebih terpaku pada tahap penyelesaian/perhitungan daripada harus menuliskan langkah-langkah perencaan mereka. Perolehan skor perencanaan kelas kontrol dan eksperimen tidak beda jauh hanya saja pada soal nomor dua jawaban peserta didik kelas eksperimen jauh lebih tepat dan lengkap dibandingkan kelas kontrol hal ini dikarenakan peserta didik kelas kontrol banyak yang tidak menuliskan perencanaan, mereka langsung menuliskan variabel terkait dan prosedur percobaannya saja.

Tahap ketiga, penyelesaian dimana peserta didik menerapkan langkah atau strategi yang telah direncanakan pada tahap dua di atas dan membentuk beberapa kegiatan yang diperlukan atau perhitungan. Setelah menerapkan langkah, peserta didik melihat dan memeriksa kembali setiap langkah dari perencanaan yang telah diproses. Pada langkah ini juga pemeriksaan dapat dilakukan secara intuitif bahkan pembuktian secara formal untuk setiap langkahnya (Billstein, Libeskind, \& Lott, 1990). Terdapat perbedaan yang cukup signifikan antara kelas eksperimen dan kontrol pada aspek penyelesaian/perhitungan, hal ini disebabkan 
karena tingkat pemahaman konsep peserta didik yang kurang sehingga tidak mampu menuliskan penyelesaian sesuai dengan perencanaan yang telah dibuat. Kebanyakan dari jawaban peserta didik kelas kontrol mampu merumuskan perencanaannya tetapi saat menuangkannya pada tahap penyelesaian kurang tepat. Peserta didik banyak yang melakukan kesalahann pada tahap ini mungkin karena proses pemecahan masalah ini adalah tahapan paling sulit yang harus dilakukan oleh peserta didik dibandingkan menganalisis, merencanakan, ataupun sekedar menerapkan konsep. Hal ini diperkuat oleh teori belajar dari Gagne yang menyatakan bahwa pemecahan masalah merupakan tipe belajar paling tinggi dari delapan tipe yang dikemukan Gagne yaitu Signal learning, stimulus-respons learning, chaning, verbal association, discrimination learning, concept learning, rule learning, dan Problem solving (Suherman, 2003).

Aspek evaluasi dimana peserta didik melakukan pemeriksaan kembali terhadap semua langkah yang telah dikerjakan (Billstein et al., 1990). Aspek ini sering sekali dilupakan oleh peserta didik saat mengerjakan soal tes karena terburu-buru mengerjakan dan menganggap jawaban mereka sudah selesai pada tahap perhitungan/penyelesaian saja. Perolehan skor aspek evaluasi kelas eksperimen dan kontrol lebih tinggi kelas eksperimen, dari sampel jawaban yang diambil terlihat bahwa peserta didik pada kelas kontrol kurang sistematis dalam menjelaskan kembali apa yang telah dijawab pada aspek-aspek sebelumnya. Berdasarkan penilaian secara keseluruhan hampir seluruh peserta didik memahami cara membuat evaluasi dengan baik dan benar hanya saja mereka cenderung malas membuatnya karena aspek ini dianggap tidak penting terlebih bagi peserta didik yang memiliki tingkan keyakinan yang tinggi akan jawabannya.

Setelah dipaparkan hasil tes peserta didik kelas eksperimen dan kontrol dapat disimpulkan bahwa terdapat perbedaan hasil tes yang signifikan antara kelas yang dibelajarkan dengan model $P B L-\mathrm{MR}$ dan kelas yang dibelajarkan dengan model $P B L$. Hasil ini sesuai dengan hasil penelitian terdahulu dimana hasil penelitian menunjukkan bahwa terdapat perbedaan yang signifikan hasil belajar kimia antara kelompok siswa yang menggunakan PBL dengan multimedia (multi representasi) dan tanpa multimedia Perbedaan yang signifikan terhadap hasil post-test kemampuan memecahkan masalah peserta didik juga dapat dilihat dari kriteria. nilai siswa dari hasil post-test, dimana sebesar $100 \%$ peserta didik kelas eksperimen memperoleh kriteria sangat baik sedangkan $41 \%$ peserta didik kelas kontrol memperoleh kriteria sangat baik, 56\% memperoleh kriteria baik, dan 3\% memperoleh kriteria cukup.

Gambar 2 terlihat bahwa terdapat perbedaan tingkat self-efficacy siswa hal ini dikarenakan kemampuan memecahkan masalah yang terdapat pada grafik hanya diukur berdasarkan nilai post-test saja sehingga selisih perolehan rata-rata nilai siswa tidak berbeda jauh, bila kemampuan memecahkan masalah peserta didik diukur pada saat proses pembelajaran sangat terlihat perbedaan tingkat memecahkan masalah peserta didik dengan self-efficacy tinggi dan rendah. Karena kemampuan memecahkan masalah peserta didik menyangkut kemampuan menggunakan percaya dri untuk menyelidiki masalah, kemampuan menerapkan penggabungan strategi pemecahan masalah, kemampuan mengenal dan merumuskan solusi, dan kemampuan menerapkan proses dari model $P B L-$ MR atau $P B L$ untuk situasi masalah dunia nyata sehingga terdapat hubungan positif yang berdampak pada adanya perbedaan kemampuan memecahkan masalah dengan tingkat self-efficacy peserta didik.

Adanya interaksi antara model pembelajaran dan tingkat self-efficacy dapat dilihat pada tabel 4. Interaksi antara model pembelajaran dan tingkat self-efficacy terhadap kemampuan memecahkan masalah peserta didik sangat terlihat pada saat fase keempat pelaksanaan model pembelajaran PBL dimana siswa yang tingkat self-efficacy tinggi dengan yakin dan percaya diri lebih mendominasi jalannya diskusi dan sesi tanya jawab berlangsung. Self-efficacy memiliki fungsi sebagai alat untuk menilai keberhasilan peserta didik dalam menyelesaikan soal-soal pemecahan masalah. Betz \& Hacket (Pajares \& Miller, 1994) barubaru ini lebih menilai self-efficacy setiap individu dalam penghakiman atas kemampuan mereka untuk memecahkan masalah tertentu dan melakukan tugas-tugas sekolah.

Kemudian menurut pendapat (Liu \& Koirala, 2009) peserta didik yang mempunyai sikap percaya diri, bahwa matematika adalah penting untuk kehidupan mereka dan membantu meraka dalam memecahkan masalah dengan menyenangkan, meskipun mereka percaya bahwa kimia adalah penting bagi mereka, tetapi mereka tidak percaya diri bahwa mereka dapat memecahkan masalah tersebut, itu berarti peserta didik tersebut memiliki self-efficacy rendah. Dengan peserta didik memiliki self-efficacy yang tinggi dan pemecahan masalah merupakan hal yang sulit untuk dikerjakan maka peranan self-efficacy bisa membuat peserta didik untuk lebih tekun dan memiliki motivasi yang tinggi untuk dapat mengerjakannya, (Bandura, 1997; Lusby, 2009) contend that self-efficacy can affect many parts of one's life such as "level of motivation and perseverance in the face of difficulties and setbacks, resilience to adversity, quality of analytical thinking”( . 1206). Sehingga self-efficacy merupakan salah satu faktor penting dalam menentukan prestasi seseorang khususnya dalam melaksanakan tugas-tugas yang berbentuk soal-soal pemecahan masalah dan terlihat bahwa antara kemampuan pemecahan masalah dan self-efficacy memiliki hubungan yang positif yang saling mendukung. Jika seorang peserta didik memiliki kemampuan pemecahan masalah yang baik, maka seorang peserta didik tersebut pun memiliki self-efficacy yang baik pula.

\section{SIMPULAN}

Berdasarkan hasil penelitian dan pembahasan dapat disimpulkan bahwa terdapat perbedaan kemampuan memecahkan masalah antara siswa yang dibelajarkan dengan menggunakan $P B L-$ MR dengan yang dibelajarkan menggunakan $P B L$. Hal ini terlihat dari perolehan nilai Sig. pada uji ANOVA dua jalur sebesar 0,000 dan juga peroleh skor tes kedua kelas dimana kelas eksperimen memperoleh rata-rata skor post-test lebih tinggi daripada kelas kontrol. Perbedaan kemampuan memecahkan masalah dengan tingkat self-efficacy yang berbeda juga terlihat dari perolehan nilai Sig. sebesar 0,028 dimana hasil tersebut membuktikan 
bahwa terdapat perbedaan kemampuan memecahkan masalah antara siswa dengan tingkat self-efficacy tinggi dan rendah. Interaksi antara model pembelajaran dan tingkat self-efficacy terhadap kemampuan memecahkan masalah cukup signifikan dengan perolehan nilai Sig. seebesar 0,042.

Model pembelajaran PBL-MR perlu diimplementasikan pada materi kimia lain yang memerlukan penyelidikan melalui suatu praktikum agar diperoleh kesimpulan penelitian yang lebih luas. Penggunaan model pembelajaran PBL-MR disesuaikan dengan karakteristik materi dimana konteks dan konten materi tersebut harus bisa dilakukan dalam suatu aktivitas laboratorium dan harus didasarkan oleh suatu permasalahan yang terjadi dalam kehidupan sehari-hari.

\section{DAFTAR RUJUKAN}

Arends, R. (2012). Learning to teach (9th editio). Boston: Mc-Graw Hill Higher Education.

Bandura, A. (1997). Self-efficacy: The Exercise of Control. New York.

Billstein, R., Libeskind, S., \& Lott, J. (1990). A Problem Solving Approach to Elementary School Teachers (4th ed.). California: Cummings Publishing Company, Inc.

Daryanto, T. R. (2015). Teori Belajar dan Proses Pembelajaran yang Mendidik. Penerbit Gava Media: Yogyakarta.

Handayani, J. (2016). Pengaruh Problem Based Learning (PBL) Berorientasi Lesson Study dengan Media eXe Learning terhadap Kemampuan Berpikir Kritis dan Hasil Belajar Siswa pada Materi Laju Reaksi. Tesis tidak diterbitkan. Universitas Negeri Medan, Medan.

Herawati, R. F., Mulyani, S., \& Redjeki, T. (2013). Pembelajaran Kimia Berbasis Multiple Representasi Ditinjau dari Kemampuan Awal terhadap Prestasi Belajar Laju Reaksi Siswa SMA Negeri I Karanganyar Tahun Pelajaran 2011/2012. Jurnal Pendidikan Kimia, 2(2), 38-43.

Imama, N., \& Nasrudin, H. (2015). Penerapan Model Pembelajaran Inkuiri untuk Melatihkan Keterampilan Berpikir Kritis Siswa pada Materi Laju Reaksi di Kelas XI SMAN 1 Sreseh Sampang. UNESA Journal of Chemical Education, 4(2), 212-217.

Jatisunda, M. G. (2017). Hubungan Self-Efficacy Siswa SMP dengan Kemampuan Pemecahan Masalah Matematis. Jurnal THEOREMS (The Original Research of Mathematics), 1(2), 24-30.

Liu, X., \& Koirala, H. (2009). The Effect of Mathematics Self-Efficacy on Mathematics Achievement of High School Students. NERA Conference Proceedings, 1-12.

Lusby, B. (2009). Increasing Students Self-Efficacy Int Mathemathics.

Mulyasa, H. (2005). Menjadi Guru Profesional. Bandung: Remaja Rosdakarya.

Musya'idah., Effendy., \& Santoso, A. (2016). POGIL, Analogi Model FAR, KBI, dan Laju Reaksi. Prosiding Semnas Pendidikan IPA Pascasarjana Universitas Negeri Malang, 671-680.

Novferma, N. (2016). Analisis Kesulitan dan Self-Efficacy Siswa SMP Dalam Pemecahan Masalah Matematika Berbentuk Soal Cerita. Jurnal Riset Pendidikan Matematika, 3(1), 76-87.

Pajares, F., \& Miller, M. D. (1994). Role of Self-Efficacy and Self-Concept Beliefs in Mathematical Problem Solving: A Path Analysis. Journal of Educational Psychology, 86(2), 193.

Sanova, A. (2013). Implementasi Metode Problem Based Learning (Pbl) Berbantuan Diagram Vee Dalam Pembelajaran Kimia Berbasis Virtual Lab untuk Meningkatkan Pemahaman Konsep Belajar. Journal of The Indonesian Society of Integrated Chemistry, 5(2), 31-38.

Suherman, E. (2003). Strategi Pembelajaran Matematika Kontemporer. Bandung: JICA.

Syaiful, B. D., \& Aswan, Z. (2006). Strategi Belajar Mengajar. Jakarta: Rineka Cipta. 